\title{
EFFECT OF CULTURE CONDITIONS ON REPRODUCTIVE TRAITS OF BROWN TROUT SALMO TRUTTA L.
}

\author{
T. RANDÁK (1), M. KOCOUR (1), V. ŽLÁBEK (1), T. POLICAR (1), J. JARKOVSKÝ (2)
}

(1) University of South Bohemia, České Budějovice, Research Institute of Fish Culture and Hydrobiology, Zátiší 728/II, 38925 Vodňany, Czech Republic.

E-Mail: randak@vurh.jcu.cz

(2) Masaryk University, Centre of Biostatistics and Analysis, Kamenice 126/3, 62500 , Brno, Czech Republic.

Reçu le 28 juin 2006

Accepté le 2 octobre 2006

Received June 28, 2006

Accepted October 2, 2006

\begin{abstract}
Progeny from artificial propagation of wild brown trout (Salmo trutta L.) of the Blanice river, Czech Republic, were farmed to maturity and spawned at ages three, four and five during 2002-2004. Reproductive parameters and biological quality of eggs in this farmed population were compared to those of the original wild population. ANCOVA showed no differences between wild and farmed fish in weight of eggs per female, total fecundity, or relative fecundity in any year. Significantly higher egg diameter $(4.57 \mathrm{~mm}$, $\mathrm{P}=0.001)$ and weight $(69.3 \mathrm{mg}, \mathrm{P}=0.0375)$ were found in the wild population in 2002 and conversely in 2004, the mean egg weight was higher in the farmed population (94.7 $\mathrm{mg}$, $P=0.0021)$. Differences in egg diameter in this year $(4.64 \pm 0.06$ and $4.82 \pm 0.06$ in wild and farmed trout, respectively) were close to the level of significance $(P=0.079)$. Mutual correlations between length or weight and studied reproductive traits were similar in both populations. Fertilization rate, duration of incubation period, egg losses during incubation and mortality of starving hatched fry were monitored in embryos and larvae of farmed population only $(F x F)$, crosses between farmed females and wild males ( $F x W)$ and wild population only $(\mathrm{WxW})$. Altogether $6.3 \%, 5.8 \%$ and $5.4 \%$ of eggs died during incubation period in FxF, FxW and WxW, respectively. There were also no significant differences in duration of incubation period and mortality of starving fry. It can be concluded that farming conditions did not significantly affect the reproductive parameters and quality of eggs in the first generation of farmed broodstock.
\end{abstract} trutta.

Key-words: Wild, farmed, reproduction, fecundity, fry, mortality, starvation, Salmo

\section{EFFET DES CONDITIONS D'ÉLEVAGE SUR LES CARACTÉRISTIQUES DE LA REPRODUCTION DE LA TRUITE FARIO SALMO TRUTTA L.}

\section{RÉSUMÉ}

Des poissons issus de la reproduction artificielle de truites fario (Salmo trutta L.) sauvages de la rivière Blanice, République Tchèque, ont été élevés jusqu'à maturité et mis à la reproduction à trois, quatre et cinq ans entre 2002 et 2004. Les paramètres de la reproduction et la qualité biologique des œufs de cette population d'élevage ont été 
comparées à celles de la population sauvage d'origine. L'ANCOVA n'a montré aucune différence entre les poissons d'élevage et sauvages pour le poids d'œufs par femelle, la fécondité totale et la fécondité relative, pour aucune des années. Le diamètre $(4,57 \mathrm{~mm}$, $P=0,001)$ et le poids $(69,3 \mathrm{mg}, \mathrm{P}=0,0375)$ d'œuf ont été significativement plus grands pour la population sauvage en 2002 et inversement en 2004, le poids moyen d'un œuf était supérieur pour la population d'élevage $(94,7 \mathrm{mg}, \mathrm{P}=0,0021)$. Les différences de diamètres des œufs de cette année $(4,64 \pm 0,06$ et 4,82 $\pm 0,06$ pour les populations sauvages et d'élevage, respectivement) étaient proches de la limite de significativité $(P=0,079)$. Les corrélations mutuelles entre longueur ou poids et les paramètres de la reproduction étudiés étaient similaires dans les deux populations. Le taux de fécondation, la durée d'incubation, la perte d'œufs durant l'incubation et la résistance des larves au jeûne à l'éclosion ont été évalués sur les embryons et les larves des populations élevées $(F x F)$, de croisement entre femelles élevées et mâles sauvages ( $F x W)$ et sauvages $(W x W)$. Globalement $6,3 \%, 5,8 \%$ et $5,4 \%$ des œufs sont morts durant la période d'incubation des FxF, FxW et WxW respectivement. Aucune différence significative n'est apparue pour la durée d'incubation ou la résistance au jeûne des larves à l'éclosion. On peut conclure que les conditions d'élevage n'ont pas affecté significativement les paramètres de la reproduction et la qualité des œufs des géniteurs de première génération d'élevage.

Mots-clés : Sauvage, d'élevage, reproduction, fécondité, larves, mortalité, jeûne, Salmo trutta.

\section{INTRODUCTION}

Brown trout (Salmo trutta m. fario L.) is native to the Czech Republic. Its occurrence is determined by water quality, temperature maxima and oxygen content. It lives for 3 to 5 years and older individuals are less abundant. It matures at age 2 to 4 years and males usually mature one year earlier than females. Relative fecundity of females in Czech brown trout populations ranges from 2000 to 3000 eggs. $\mathrm{kg}^{-1}$. Related to water temperature, the egg development time from fertilization to hatching ranges from 260 to 520 degree-days (D.D. = days $\left.\times{ }^{\circ} \mathrm{C}\right)$ (LIBOSVÁRSKÝ, 1967; LUSK, 1968a,b; LUSK, 1969). Due to various factors such as unfavourable regulation of streams, increasing fishing pressure, predators, anthropogenic pollution, improper management of fishing grounds, etc., brown trout stocks in streams and rivers of the Czech Republic have been decreasing for many years. Production of fish for restocking cannot be further enhanced by the traditional way due to the lack of spawners, as it depends on their capture in open waters, their spawning and extensive rearing of fry in breeding brooks. For this reason spawners have been farmed to enhance significantly the amount of restocking material.

Farming conditions can significantly affect natural selection already at the egg stage. The optimal size of eggs in a natural environment depends to a large extent on the quality of the spawning substrate, while natural selection usually favours smaller eggs (VAN DEN BERGHE and GROSS, 1989). Under the conditions of fish farming, the size of eggs produced by farmed broodstock usually increases (FLEMING and GROSS, 1990, 1992; PETERSSON and JÄRVI, 1993). Bigger eggs are a prerequisite for producing bigger fry (FOWLER, 1972; BEACHAM et al., 1985). A consequent increase of size of farmed fish thus occurs in fish farms (PETERSSON and JÄRVI, 1993; RUZZANTE, 1994). Changes in genetic information may happen due to farming of originally wild fish populations. Most work on such genetic differences from original populations has focused on fish populations which have been farmed for several generations (SWAIN and RIDDELL, 1990; BEREJIKIAN et al., 1996; FLEMING and EINUM, 1997; DEVERILL et al., 1999). However, VERSPOOR (1988) gave examples of significant changes which had happened already during the first generation of farmed Atlantic salmon (Salmo salar L.) due to genetic drift. Experiences of an individual gained under farming conditions during a short period may 
result in phenotypic changes without any genetic differences from the original population (FLEMING and EINUM, 1997; METCALFE et al., 2003). If brood fish are farmed artificially, the phenotype of the progeny may be affected due to maternal effects (MOUSSEAU and FOX, 1998). Although the phenotypic changes induced by effects of farming conditions do not have any great evolutionary importance, they can significantly affect adaptability and viability of artificially reared individuals, stocked into natural conditions (EINUM and FLEMING, 2001).

The present study assessed changes in several reproductive parameters during the first generation of farmed brood fish. It was performed during three consecutive spawning seasons. Values of the parameters recorded for farmed fish in the respective years were compared with those found for similarly sized specimens of the original wild population. The original wild brown trout population, from the progeny of which the brood fish have been farmed, was used as a reference standard.

\section{MATERIAL AND METHODS}

\section{Experimental place}

The study was carried out at the Husinec hatchery of the Czech Anglers'Union $\left(49^{\circ} 03^{\prime} \mathrm{N}, 1^{\circ} 01^{\prime} \mathrm{E}, 500 \mathrm{~m}\right.$ above sea level) in $1999-2004$. The hatchery is located on the Blanice river (river $\mathrm{km} \mathrm{56}$ ) downstream of the Husinec dam reservoir ( $37 \mathrm{ha}$; $2.5 \times 10^{6} \mathrm{~m}^{3}$ ) in the southwest part of the Czech Republic. The hatchery was supplied with river water. The total length of Blanice river is $83 \mathrm{~km}$, the length of the stretch with brown trout occurrence is approximately $40 \mathrm{~km}$. Average annual water temperature in experimental place was 8.9 $\pm 6.7^{\circ} \mathrm{C}$, and annual mean discharge into the Blanice river was $1.7 \pm 1.7 \mathrm{~m}^{3}$.

\section{Wild brood fish sampling}

Wild fish were caught every year in the second half of October with a pulsed-DC electrofisher in the protected fish area of the Blanice river (river km $52-57$ ). Males and females were stored separately in flow-through concrete tanks. Ripe fish were handstripped and then released back to the Blanice river. Eggs were incubated in hatchery trays. The fry obtained from these eggs were usually released into small tributaries of the Blanice river. A part of the fry hatched in April 2000 was reared under farming conditions in order to produce the broodstock.

\section{Brood fish rearing}

Rearing of brown trout from fry (spring 2000) until brood fish (autumn 2002) was performed intensively in flow-through concrete tanks. The tanks volumes were $8 \mathrm{~m}^{3}$ $\left(1500-2000\right.$ fry. $\mathrm{m}^{-3}$ ) and $20 \mathrm{~m}^{3}$ (250 one-year-old fish. $\mathrm{m}^{-3}, 100$ two-year-old fish. $\mathrm{m}^{-3}$, or 25-50 brood fish. $\mathrm{m}^{-3}$ ) for the first and subsequent years of rearing, respectively. Fish were fed pellets originally designed for rainbow trout (Oncorhynchus mykiss Walbaum) with the content of fat below $16 \%$. The photoperiod was natural. Almost all males were selected out during the first artificial reproduction (2002). In the consecutive years the eggs of reared females were fertilized by the milt of wild males only. No other voluntary selection was applied during 2000 - 2004. The first hand-stripping was carried out in 2002 (three-year-old fish), the second one in 2003 (four-year-old fish) and the third one in 2004 (five-year-old fish). Similar size wild fish caught in the Blanice river at $\mathrm{km} 52-57$ were hand-stripped at the same times and were used as control groups (wild fish).

\section{Stripping}

Before stripping, ripe females were anaesthetized with a $0.3 \mathrm{ml} . \mathrm{I}^{-1}$ solution of 2phenoxyethanol and standard length and total weight of every specimen were recorded to 
the nearest $1 \mathrm{~mm}$ and $0.1 \mathrm{~g}$, respectively. Both groups of fish (wild and farmed) were handstripped at the same time. All the females were always hand-stripped between October 30 and November 15 in 2002, 2003 and 2004. Fecundity parameters were detected during the first hand-strippings from random samples of approximately 30 females per group. Eggs of each female were weighed to the nearest $0.01 \mathrm{~g}$. A sample of 30 unfertilized eggs from each female was taken to determine egg size and weight. The mean egg diameter was determined by measuring 10 eggs with calipers to the nearest $0.1 \mathrm{~mm}$. Egg weight was recorded to the nearest $0.001 \mathrm{~g}$.

\section{Biological quality of eggs}

The assessment of biological quality of eggs was carried out in 2002 when fish sizes were still comparable in wild and farmed populations. The goal was to compare the batches of eggs for duration of the incubation period, egg losses during incubation and the course of mortality of starving fry.

Three following batches of eggs were compared:

- eggs from 15 wild females fertilized by the pooled milt of 10 wild males $(W \times W)$,

- eggs from 15 farmed females fertilized by the pooled milt of 10 wild males (FxW),

- eggs from 15 farmed females fertilized by the pooled milt of 10 farmed males $(\mathrm{FxF})$.

Hand-stripped eggs of each group of females were collected in individual bowls. Sperm was collected individually (10 wild males, 10 farmed males) into $5 \mathrm{ml}$ plastic syringes. $1 \mathrm{ml}$ of sperm was taken from each male. After milt collection, the syringes were stored on ice to fertilization (maximally for $20 \mathrm{~min}$ ). Fertilization of each group of eggs was performed using $5 \mathrm{ml}$ of pooled milt from ten males $(0.5 \mathrm{ml}$ from each male). The groups of eggs WxW and FxW were fertilized with milt from the same males. Clear water was added to assist fertilization. The solution was gently swirled for 60s and then washed clean. After fertilization the eggs were allowed to swell for 15 min. Then three hundred eggs from each group were placed for incubation in three trays (100 eggs/tray) located in hatchery troughs. Dead eggs were counted and removed daily. The dead eggs, counted before the eyed stage, were used as a measure of fertilization success (ESTAY et al., 2004). Water temperature and numbers of dead eggs were recorded throughout incubation. Water flowed through hatchery troughs between $5-10 \mathrm{I} \cdot \mathrm{min}^{-1}$. The quality of the eggs was assessed after emergence by checking the daily mortality of starving fry until all stock had died (BEREJIKIAN et al., 1999, MIGAUD et al., 2001).

\section{Statistical analyses}

The data obtained were processed for each year (2002-2004) separately and also together for the whole three-year period, to compare individual reproductive parameters of both the wild riverine population and the farmed (pond-reared) fish. Standard length and spawner weight were compared by ANOVA. Reproductive parameters were compared by ANCOVA with standard length as covariate. ANCOVA was used to eliminate the fish size differences between wild and farmed populations. Differences in the traits studied were compared by Tukey's multiple range test $(\alpha<0.05)$ in Statgraphics software v. 5 .

The distribution functions of the time of fry death $\left(F_{\mathrm{W} \times W}, F_{F x F}, F_{F x W}\right)$ were computed. These distribution functions were compared using the Kolmogorov-Smirnov test (KS test). The null hypothesis was that the distribution functions did not differ, e.g.: $\mathrm{H}_{0}: \mathrm{F}_{\mathrm{W} \times \mathrm{W}}=\mathrm{F}_{\mathrm{FxF}}$, the alternative hypothesis was that the distribution functions differed, e.g. $\mathrm{H}_{\mathrm{A}}: \mathrm{F}_{\mathrm{W} \times \mathrm{W}} \neq \mathrm{F}_{\mathrm{FxF}}$ : The critical value of the tests was approximated (Massey, 1951). The level of the tests was adjusted using the Bonferroni correction. 


\section{RESULTS}

\section{Reproductive characteristics}

Both the wild and farmed fish matured in the same period, during all the years under study. Two artificial propagations were carried out annually during October 30 - November 15.

Body lengths and spawner weights of farmed fish were significantly higher than wild fish in 2003 and 2004. ANCOVA showed no differences between wild and farmed fish in weight of eggs per female, total fecundity, or relative fecundity in any year. Significantly higher egg diameter $(4.57 \mathrm{~mm}, \mathrm{P}=0.001)$ and weight $(69.3 \mathrm{mg}, \mathrm{P}=0.0375)$ were found in the wild population in 2002 and conversely in 2004, the mean egg weight was higher in the farmed population ( $94.7 \mathrm{mg}, \mathrm{P}=0.0021)$. Differences in egg diameter in this year (4.64 \pm 0.06 and $4.82 \pm 0.06$ in wild and farmed trout, respectively) were close to the level of significance $(P=0.079)$ (Table I).

Mutual correlations between length or weight and studied reproductive traits were similar in both populations. Linear relationship was considered as the most probable on the base of found regression coefficients. Weight of eggs per female $\left(W_{E}\right)$ and total fecundity $\left(F_{T}\right)$ were slightly more dependent on spawner weight $\left(W_{S}\right)$ than on standard length $\left(\mathrm{L}_{\mathrm{S}}\right)$ in the farmed population $\left(\mathrm{W}_{\mathrm{E}}: \mathrm{W}_{\mathrm{S}} r=0.96, \mathrm{n}=90, \mathrm{P}<0.001\right.$ and $\mathrm{W}_{\mathrm{E}}: \mathrm{L}_{\mathrm{S}} r=0.93$, $\mathrm{n}=90, \mathrm{P}<0.001 ; \mathrm{F}_{\mathrm{T}}: \mathrm{W}_{\mathrm{S}} r=0.94, \mathrm{n}=90, \mathrm{P}<0.001$ and $\left.\mathrm{F}_{\mathrm{T}}: \mathrm{L}_{\mathrm{S}} r=0.90, \mathrm{n}=90, \mathrm{P}<0.001\right)$, while in the wild population it was the opposite $\left(\mathrm{W}_{\mathrm{E}}: \mathrm{W}_{\mathrm{S}} r=0.77, \mathrm{n}=83, \mathrm{P}<0.001\right.$ and $\mathrm{W}_{\mathrm{E}}: \mathrm{L}_{\mathrm{S}} r=0.80, \mathrm{n}=83, \mathrm{P}<0.001 ; \mathrm{F}_{\mathrm{T}}: \mathrm{W}_{\mathrm{S}} r=0.51, \mathrm{n}=83, \mathrm{P}<0.001$ and $\mathrm{F}_{\mathrm{T}}: \mathrm{L}_{\mathrm{S}} r=0.56, \mathrm{n}=$ $83, \mathrm{P}<0.001)$. On the other hand, egg diameter, egg weight and relative fecundity were more dependent on standard length in the farmed population and the spawner weight in the wild population (Figure 1).

\section{Biological quality of eggs}

Altogether $4.5 \%, 0.6 \%$ and $2.2 \%$ eggs died in the egg batches $\mathrm{WxW}$, FxW and FxF, respectively, from stocking the eggs in trays (November 2, 2002) until the eyed stage (February 5, 2003; 284 D.D. since the beginning of incubation in all egg batches). Mean water temperature at the hatchery fluctuated around $3.0 \pm 1.5^{\circ} \mathrm{C}$ in this period. Fry hatched in the same period from all egg batches (March 27 - April 2, 2003), i.e. in 355 - 380 D.D. from the beginning of incubation. All fry had hatched in all batches by April 2. Altogether $1.8 \%, 5.2 \%$ and $3.2 \%$ of eggs and freshly hatched larvae died in WxW, FxW and FxF batches, respectively, after the eyed stage. Mean body weight of hatched fry WxW was $67.0 \pm 7.08 \mathrm{mg}$, FxW $63.6 \pm 5.24 \mathrm{mg}$ and FxF $63.3 \pm 5.36 \mathrm{mg}$. The last starving fry of all groups died on June 3, 2003 (558 D.D. since the end of hatching) (Figure 2). Mean water temperature in the hatchery was $8.9 \pm 3.6^{\circ} \mathrm{C}$ during the period from hatching until the death of the last specimens.

The Kolmogorov-Smirnov tests comparing the distribution of fry deaths in different matings gave the following values: $D_{W \times W, F x F}=0.198, D_{F x W, F x F}=0.119, D_{W \times W, F \times W}=0.143$. The estimated critical value was $D_{300,300}^{*}(0.01667)=0.1263$. The number of cases in each group was 300 , and the adjusted level of the test was 0.01667 . On this basis the distribution function of the WW-mating was statistically different from both those of the FF and FW matings. Cumulative mortality of the WxW fry was higher than those of the FxW and FxF fry during the 110th - 112th days of the experiment. Conversely, the cumulative mortalities of the FxW and FxF were higher during the 115th - 117th days of the experiment (Figure 2). 


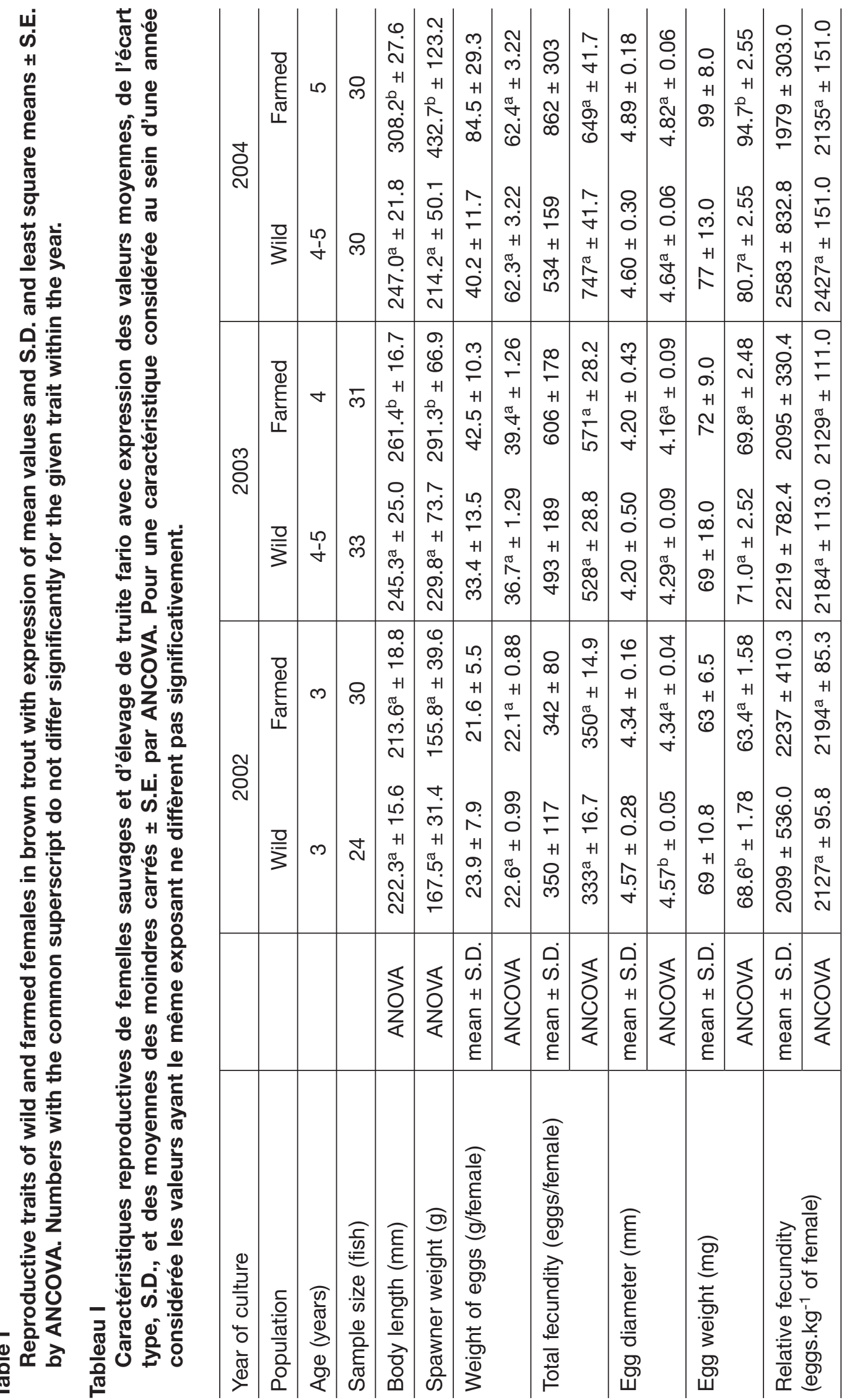



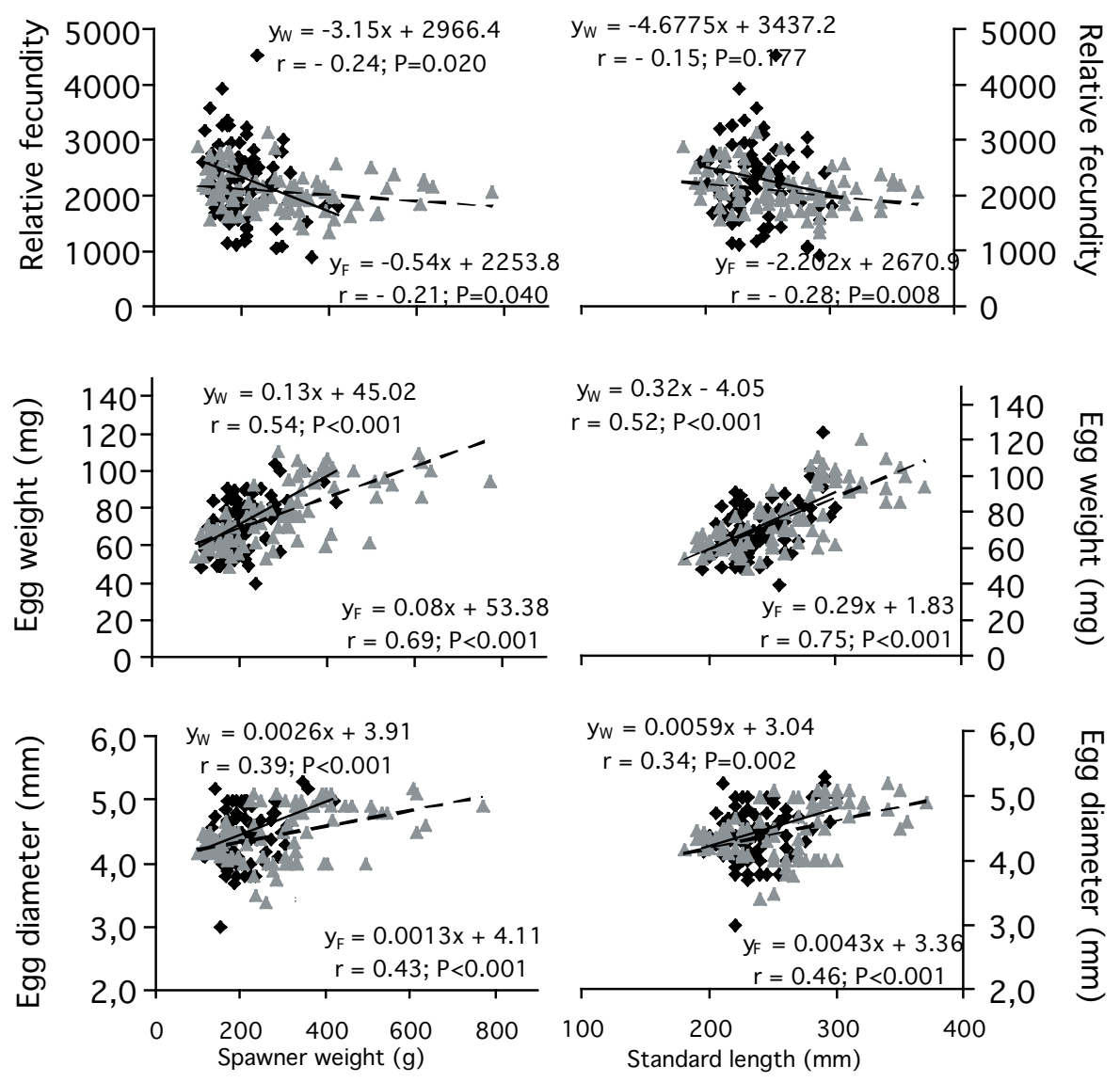

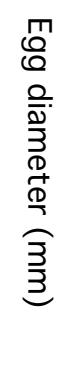

Figure 1

Effect of spawner weight and standard length in wild $(\diamond)$ and farmed (A) population of brown trout on egg size, egg weight and number of eggs per kg of b.w. Estimated linear correlations are on the top of each graph for the wild and on the bottom for the farmed population.

\section{Figure 1}

Relation du poids et de la longueur standard des géniteurs des populations sauvages $(\diamond)$ et d'élevage $(\Delta)$ de truite fario avec la taille, le poids et le nombre d'œufs par kilo de poids brut. Les corrélations linaires estimées sont indiquées en haut de chaque graphe pour les populations sauvages et en bas pour les populations d'élevage.

\section{DISCUSSION}

Farmed spawners matured at age $2-4$ years and most matured in the 3rd year. ESTAY et al. (2004) found the same results with farmed brown trout under Chilean aquaculture conditions. The age at which the farmed fish matured did not differ from natural conditions (TAUBE, 1976; LUSK, 1968a). Reproduction of the farmed fish annually occurred in November, which was the usual period under conditions corresponding to this latitude (PENDER and KWAK, 2002). The reproductive period of the farmed fish corresponded with that of the reference wild population. 
Days 0-111 (6th February - 27th May 2003)

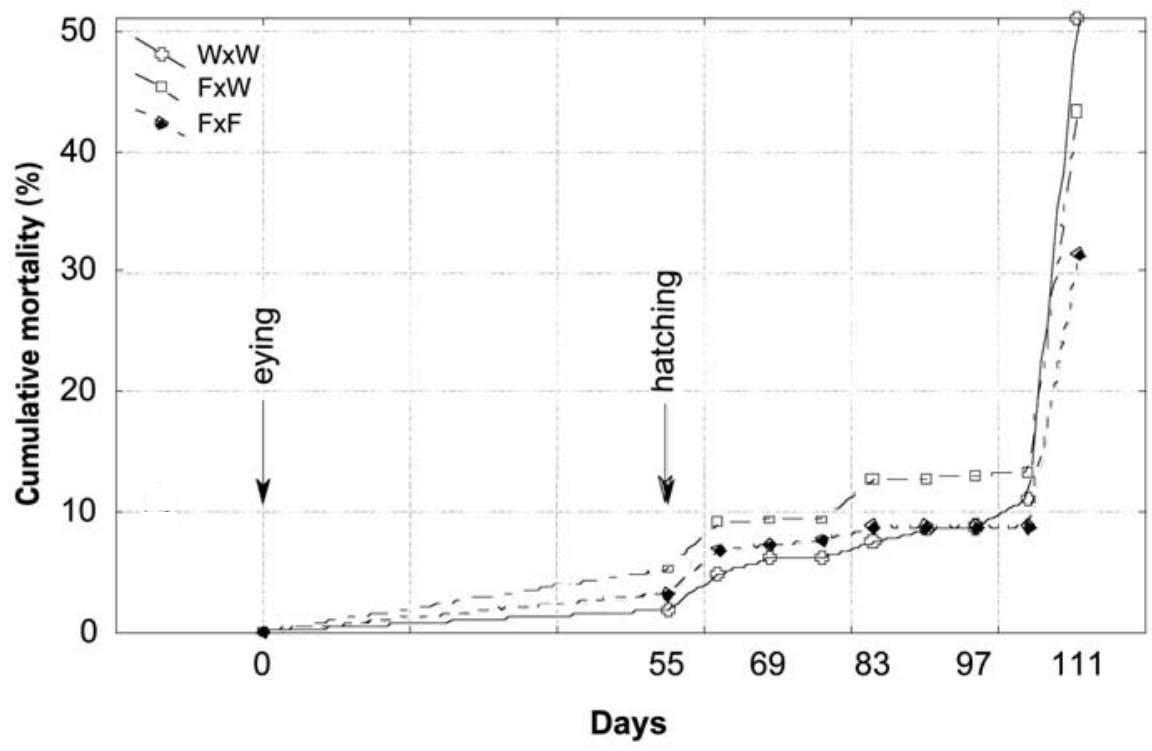

Days 111-118 (27th May - 3rd June 2003)

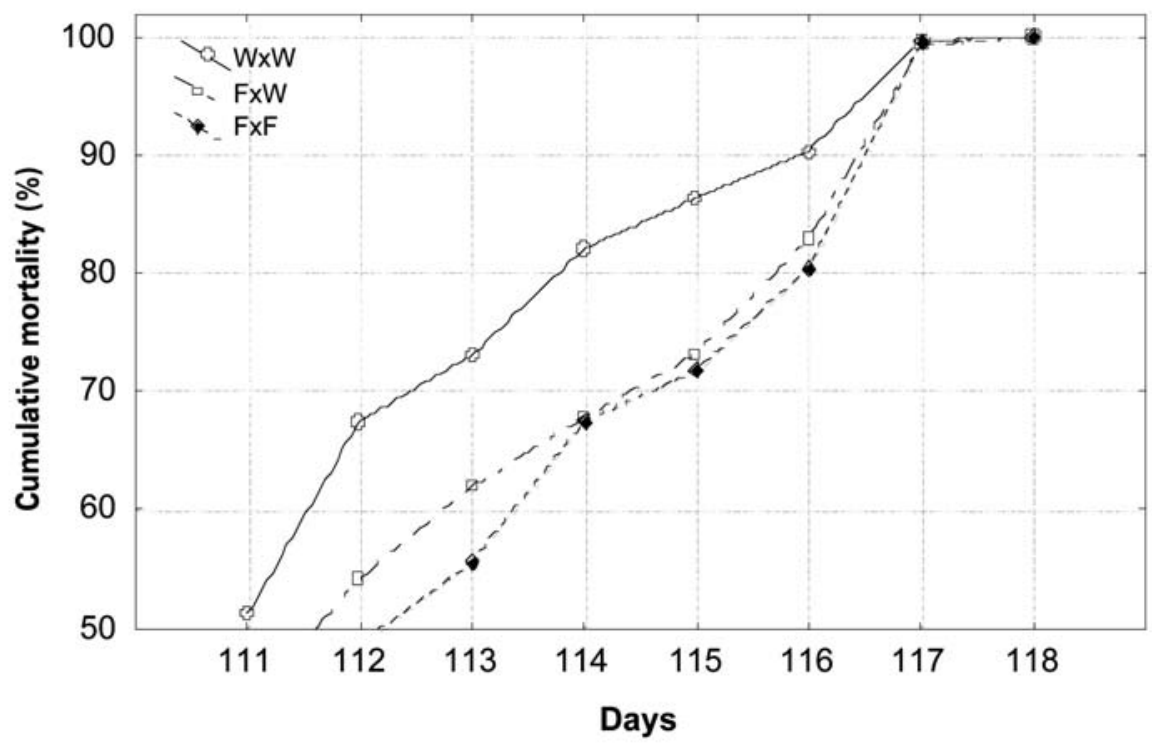

Figure 2

Cumulative mortality of brown trout eggs and unfed fry in tested groups. WxW eggs from wild females fertilized by wild males milt; FxW - eggs from farmed females fertilized by wild males milt; FxF - eggs from farmed females fertilized by farmed males milt.

Figure 2

Mortalité cumulée des œufs de truite fario et des alevins non nourris dans les lots testés. WxW - œufs de femelles sauvages fertilisées par de la laitance de mâles sauvages; FxW - œufs de femelles d'élevage fertilisées par de la laitance de mâles sauvages; FxF - œufs de femelles d'élevage fertilisées par de la laitance de mâles d'élevage. 
Total fecundity and relative fecundity of both wild and farmed fish in individual years were average for the brown trout at the same age and the similar size (GARCIA and BRANA, 1988; LUSK, 1968b).

Weight of eggs per female and total fecundity were strongly related to the standard length and spawner weight, mainly with the spawner weight in the farmed fish, and with the standard length in the wild fish. Stronger relationships were found for the farmed fish. Egg diameter, egg weight and relative fecundity relationships to size parameters of the broodstock were also proven, but not so unequivocally as in the previous cases (Fig. 1). Stronger relationships with the standard length were found for the farmed fish and correlations for the spawner weight were similar for both populations. Similar relationships of the reproductive parameters with the size of brood fish have been found by many authors (MCFADDEN et al., 1965; BAGENAL, 1969; OJANGUREN et al., 1996; L'ABÉELUND and HINDAR, 1990; LOBON-CERVIA et al., 1997).

As the wild and farmed fish differed in size, parameters for comparison were standardized by ANCOVA (Table I). Significant differences were few, so it was concluded that the conditions of brown trout farming did not significantly affect the reproductive traits studied.

The goal of the experiments was to assess if brood fish farming leads to any decrease in gamete quality followed by decreased viability of their progeny. The size of the fry, which is closely associated with its survival, correlates positively with egg size. It has been established that fry survival depends on egg size only during the period of yolk sac absorption and during the first few weeks of exogenous nutrition (HUTCHINGS, 1991; SPRINGATE and BROMAGE, 1985; EINUM, 2003). In the present experiment, the mean size of the eggs of 3-year-old farmed fish (F) was slightly smaller than that of wild fish (W) of a similar body size (Table I). Egg fertilization rate, assessed by the number of dead eggs per batch until the eyed-ova stage, were $96 \pm 3.5 \%$ in the WxW, $99 \pm 0.7 \%$ in the FxW and $98 \pm 1.5 \%$ in the FxF batches. From eyeing until the end of hatching, $2 \pm 0.6 \%$ of eggs and freshly hatched larvae died in the WxW, $5 \pm 2.6 \%$ in the FxW and $3 \pm 0.7 \%$ in the FxF batches. There were no significant differences in fertilization rate and in mortality rate after eyeing between the groups compared. Duration of egg incubation of wild females and farmed females was the same (355 - 380 D.D.). Mean weight of hatched fry of wild females (WxW) was slightly higher compared to that of farmed females (FxW and FxF). This was probably due to the larger size of eggs of wild fish (FOWLER, 1972; BEACHAM et al., 1985). The pattern of starving fry mortality was very similar in all groups tested. Several individuals died each week in all groups during the first 55 days post hatching (450 D.D. since hatching). On May 26 (56 days after hatching) there was a sudden increase in the mortality rate in all groups. During this period the fry had probably depleted the nutrients from the yolk sac. Despite the statistical analysis of cumulative mortality, which showed a slightly different course in the WxW group compared with the crosses, differences between the progeny of farmed and wild fish were minimal. This was also supported by the fact that the death of the last specimens occurred on the same day in all groups (day 63; 558 D.D. since hatching). So farming conditions did not significantly affect the quality of the eggs and the progeny. JARRAMS (1979) also drew similar conclusions for Atlantic salmon and sea trout (Salmo trutta L.) but found a lower fertilization rate for eggs of farmed fish. In the present case, the fertilization rate of eggs of farmed fish was higher than those of wild fish.

Thus the culture conditions did not significantly affect the reproductive parameters studied in the first generation of farmed brown trout brood stock. Farmed fish showed the same reproductive cycles as their wild counterparts, and the biological quality of eggs of the studied groups of fish was similar. 


\section{ACKNOWLEDGEMENTS}

This study was supported by the USB RIFCH no. MSM6007665809 and by the Ministry of Agriculture of the Czech Republic project no. QF3028. The authors of this paper gratefully thank to the Czech Anglers'Union for technical support. The authors gratefully thank John E. Thorpe for the language assistance and Jean-Thomas Vuillard for translation of the French abstract.

\section{REFERENCES}

BAGENAL T.B., 1969. Relationship between egg size and fry survival in brown trout Salmo trutta L. J. Fish. Biol., 1, 349 - 353.

BEACHAM T. D., WITHLER F. C., MORLEY R. B., 1985. Effect of egg size on incubation time and alevin and fry size in chum salmon (Oncorhynchus keta) and coho salmon (Oncorhynchus kisutch). Can. J. Zool., 63, 847 - 850.

BEREJIKIAN B. A., MATHEWS S. B., QUINN T. P., 1996. Effects of hatchery and wild ancestry and rearing environments on the development of agonistic behavior in steelhead trout (Oncorhynchus mykiss) fry. Can. J. Fish. Aquat. Sci., 53, 2004 - 2014.

BEREJIKIAN B.A., TEZAK E.P., SCHRODER S.L., FLAGG T.A., KNUDSEN C.M., 1999. Competitive Differences between Newly Emerged Offspring of Captive-Reared and Wild Coho Salmon. T. Am. Fish. Soc., 128 (5), 832 - 839.

DEVERILL J.I., ADAMS C.E., BEAN C.W., 1999. Prior residence, aggression and territory acquisition in hatchery-reared and wild brown trout. J. Fish. Biol., 55, 868 - 875.

EINUM S., 2003. Atlantic salmon growth in strongly food-limited environments: Effects of egg size and paternal phenotype? Environ. Biol. Fish., 67, 263 - 268.

EINUM S., FLEMING I. A., 2001. Implications of stocking: Ecological interactions between wild and released salmonids. Nordic Journal of Freshwater Research, 75, 56 - 70.

ESTAY F.J., NORIEGA R., URETA J.P., MARTIN W., COLIHUEQUE N., 2004. Reproductive performance of cultured brown trout (Salmo trutta L.) in Chile. Aquac. Res., 35, 447 $-452$.

FLEMING I. A., GROSS M. R., 1990. Latitudinal clines: A trade-off between egg number and size in Pacific salmon. Ecology, 71, 1 - 11.

FLEMING I. A., GROSS M. R., 1992. Reproductive behavior of hatchery and wild coho salmon (Oncorhynchus kisutch): does it differ? Aquaculture, 103, 101 - 121.

FLEMING I. A., EINUM, S., 1997. Experimental tests of genetic divergence of farmed from wild Atlantic salmon due to domestication. ICES Journal of Marine Science, 54, 1051 - 1063.

FOWLER L. G., 1972. Growth and mortality of fingerling chinook salmon as affected by egg size. Progressive Fish Culturist, 34(2), 66 - 69.

GARCIA A., BRANA F., 1988. Reproductive biology of brown trout (Salmo trutta L) in the Aller River (Asturias; Northern Spain). Polskie Archiwum Hydrobiologii, 35, 361 $-373$.

HUTCHINGS J.A., 1991. Fitness consequences of variation in egg size and food abundance brook trout Salvelinus fontinalis. Evolution, 45, 1162 - 1168.

JARRAMS P., 1979. Egg, fry and smolt production from salmon, Salmo salar L. and sea trout Salmo trutta L. reared entirely in fresh water. J. Fish. Biol., 15, 607 - 611.

L'ABÉE-LUND J.H., HINDAR K., 1990. Interpopulation variation in reproductive traits of anadromous female brown trout, Salmo trutta L. J. Fish. Biol., 37, 755 - 763. 
LIBOSVÁRSKÝ J., 1967. The spawning run of brown trout, Salmo trutta m. fario L., and its analyses. Folia Zool.,16, 73 - 86.

LOBON-CERVIA J., UTRILLA C.G., RINCÓN P.A., AMEZCUA F., 1997. Environmentally induced spatio-temporal variations in the fecundity of brown trout Salmo trutta L.: Trade-offs between egg size and number. Freshwater Biol., 38, 277 - 288.

LUSK S., 1968a. Sexual maturity, sex ratio and fecundity in the brown trout, Salmo trutta m. fario L., in the Loučka River. Folia Zool., 17, 253 - 268.

LUSK S., 1968b. Egg and milt production in the brown trout (Salmo trutta morpha fario L.) in the Loučka Creek. Folia Zool., 17, 363 - 378.

LUSK S., 1969. Changes in gonad weight and amount of fats in the brown trout, Salmo trutta $m$. fario L., in the course of a year. Folia Zool., 18, 67 - 80.

MASSEY F. J., 1951. The Kolmogorov-Smirnov test for goodness of fit. Journal of the American Statistical Association, 46, 68 - 78.

MCFADDEN J.T., COOPER E.L., ANDERSEN J.K., 1965. Some effects of environment on egg production in brown trout (Salmo trutta). Limnol. Oceanogr., 10, 88 - 95.

METCALFE N. B., VALDIMARSSON S. K., MORGAN I. J., 2003. The relative roles of domestication, rearing environment, prior residence and body size in deciding territorial contests between hatchery and wild juvenile salmon. J. Appl. Ecol. 40: $535-544$.

MIGAUD H., GARDEUR J.N., FORDOXCEL L., FONTAIN P., BRUN-BELLUT J., 2001. Influence of the spawning time during the reproduction period on the larval quality of euroasian perch, Percha Fluviatilis. Europian Aquaculture Society, Special Publication No. 30, Ostende, Belgium.

MOUSSEAU T. A., FOX C. V., 1998. The adaptive significance of maternal effects. Trends Ecol. Evol., 13, 403 - 407.

OJANGUREN A.F., REYES-GAVILAN F.G., BRANA F., 1996. Effects of egg size on offspring development and fitness in brown trout, Salmo trutta L. Aquaculture, 147, 9 - 20.

PENDER D.R., KWAK T.J., 2002. Factors influencing brown trout reproductive success in Ozark Tailwater Rivers. T. Am. Fish. Soc.,131, 698 - 717.

PETERSSON E., JÄRVI T., 1993. Differences in reproductive traits between sea-ranched and wild sea-trout (Salmo trutta) originating from a common stock. Nordic Journal of Freshwater Research, 68, 91 - 97.

RUZZANTE D. E., 1994. Domestication effects on aggressive and schooling behavior in fish. Aquaculture, 120, 1 - 24.

SPRINGATE J.R.C., BROMAGE R.E., 1985. Effects of egg size on early growth and survival in rainbow trout (Salmo gairdneri Richardson). Aquaculture, 47, 163 - 172.

SWAIN D.P., RIDDELL B.E., 1990. Variation in agonistic behaviour between newly emerged juveniles from hatchery and wild populations of coho salmon, Oncorhynchus kisutch. Can. J. Fish. Aquat. Sci., 47, 566 - 571.

TAUBE C.M., 1976. Sexual maturity and fecundity in brown trout of the Platte River, Michigan. T. Am. Fish. Soc., 105, 529 - 533.

VAN DEN BERGHE E. P., GROSS M. R., 1989. Natural selection resulting from female breeding competition in a Pacific salmon (coho: Oncorhynchus kisutch). Evolution, 43, $125-140$.

VERSPOOR E., 1988. Reduced genetic variability in first-generation hatchery populations of Atlantic salmon (Salmo salar). Can. J. Fish. Aquat. Sci., 45, 1686 - 1690. 
